This is the version of the article accepted for publication in Journal of Business Ethics published by Springer: https://doi.org/10.1007/s10551-015-2827-6

Accepted version downloaded from SOAS Research Online: http://eprints.soas.ac.uk/21206

\title{
How Servant Leadership Influences Organizational Citizenship Behavior: The Roles of LMX, Empowerment and Proactive Personality
}

(Newman, A., G. Schwarz, B. Cooper, and S. Sendjaya)

\begin{abstract}
While the link between servant leadership and organizational citizenship behavior (OCB) has been established, the individual-level mechanisms underlying this relationship and its boundary conditions remain poorly understood. In this study, we investigate the salience of the mediating mechanisms of leader-member exchange (LMX) and psychological empowerment in explaining the process by which servant leaders elicit discretionary OCB among followers. We also examine the role of followers' proactive personality in moderating the indirect effects of servant leadership on OCB through LMX and psychological empowerment. Analysis of survey data collected from 446 supervisor-subordinate dyads in a large Chinese multinational firm suggests that while servant leadership is positively related to subordinate OCB through LMX, psychological empowerment does not explain any additional variance in OCB above that accounted for by LMX. Moderated mediation tests confirm the moderating effect of proactive personality through LMX. By providing a nuanced understanding of how and when servant leadership leads followers to go above and beyond their job role, our study assists organizations in deciding how to develop and utilize servant leaders in their organizations.
\end{abstract}

\section{Keywords}

LMX; Organizational citizenship behavior; Psychological empowerment; Servant leadership 


\section{Introduction}

Over the last decade, growing empirical research has highlighted the utility of servant leadership as a management technique that enables business organizations to develop and maintain a competitive advantage. Servant leadership refers to a leadership approach by which leaders set aside their self-interest and altruistically work for the benefit of their followers, and the communities in which they operate (Avolio et al. 2009; Parris and Welty Peachey 2013). Servant leaders invest in the development of their followers by acting as role models who provide support, involve followers in decision-making, display appropriate ethical behavior, and stress the importance of serving the wider community in which they are embedded (Reed et al. 2011; Stone et al. 2004). Empirical evidence suggests that servant leaders foster more satisfied, committed, engaged and better-performing followers (Carter and Baghurst 2013; Liden et al. 2008; Mayer et al. 2008; Neubert et al. 2008).

Research has revealed that servant leaders make followers go beyond their job role to exhibit organizational citizenship behavior (OCB) (Ehrhart 2004; Reed 2015; Walumbwa et al. 2010), defined as discretionary behavior that is not recognized by the formal reward system and promotes the effective functioning of the organization (Organ 1988). As highlighted in a recent systematic review of the literature (Parris and Welty Peachey 2013), prior research considering the effects of servant leadership has typically measured OCB at the team level, and focused on team-level mediators such as procedural justice and service climates (Ehrhart 2004; Hunter et al. 2013). There has, however, been limited examination of the relative importance of the different psychosocial processes underlying this relationship at the individual level of analysis. In addition, there has been a dearth of research on the boundary conditions of the relationship between servant leadership and work outcomes. For example, although exploratory work has begun to look at the relationship between followers' personality dimensions and servant leadership (Reed 2005), prior research has not examined 
how followers' personalities and other individual differences influence how followers respond to servant leadership. Better understanding of how, and in which situations, servant leadership leads followers to go above and beyond their job role is of critical importance to managers when deciding how to develop and mobilize servant leaders in their organizations.

To address these gaps in the literature, the present study asks two main questions. First, it asks whether servant leadership elicits followers to engage in greater OCB by enhancing the quality of their relationship with their supervisor, as captured by Leader-Member Exchange (LMX) and/or by heightening their psychological empowerment, defined as an individual's motivation to perform tasks. Although such mechanisms have been suggested as possible explanations for the effects of servant leadership on followers' OCB in the extant literature (Henderson et al. 2009; Liden et al. 2008; Russell and Stone 2002; Van Dierendonck 2011), they have not yet been examined in a single study. Understanding the relative effects of LMX and psychological empowerment will allow us to make a theoretical contribution by testing the salience of social exchange theory (Blau 1964) and intrinsic motivation theory (Ryan and Deci 2000) as individual-level psychosocial processes by which servant leadership leads followers to engage in OCB. Second, the present study asks whether the proactive personality of followers strengthens the influence of servant leadership on OCB by facilitating the building of strong relationships with their supervisor as captured by LMX, and by motivating them to perform in the workplace. We chose to focus on proactive personality, which has been defined as an individual's behavioral tendency to identify opportunities to enact change and manipulate the environment to act on such opportunities (Crant 2000) because it has been shown to be a stronger predictor of employee OCB than other personality measures (Fuller and Marler 2009) and influences the propensity of employees to build productive relationships in the workplace and maintain high levels of intrinsic motivation ( $\mathrm{Li}$ et al. 2010; Thompson 2005; Yang et al. 2011; Zhang et al. 2012). By 
focusing on whether proactive personality moderates the influence of servant leadership behavior, we address the calls of researchers for greater investigation into how individual differences among followers, such as personality, influence how they perceive and respond to different styles of leadership (Antonakis et al. 2012; Zaccaro 2012). Although previous work has shown that personality characteristics influence how followers respond to leadership behavior (Ehrhart and Klein 2001), limited research has investigated whether follower's personality may accentuate or attenuate the effects of servant leadership.

By investigating these issues, our work brings important practical benefits. As well as providing an in-depth understanding of the process by which servant leaders engender greater discretionary behavior amongst followers, our study also identifies which followers may benefit most from being placed with servant leaders. This knowledge will allow organizations to better deploy servant leaders to the maximum benefit of the organization. Figure 1 illustrates the research framework of our study.

\section{INSERT FIGURE 1 ABOUT HERE}

In the following sections, we review the literature on servant leadership and the mechanisms linking servant leadership to work outcomes and their boundary conditions before presenting our hypotheses. We then explain how the data were collected and analyzed, and present our findings. Finally, we discuss our findings and their implications before presenting suggestions for future research.

\section{Literature Review}

In this section, we review the literature on servant leadership and its relationship with follower OCB. We then review the literature on LMX, psychological empowerment and 
proactive personality, and develop hypotheses concerning the mediating effects of LMX and psychological empowerment, and the moderating effects of proactive personality.

Servant Leadership

Although servant leadership has been measured in numerous ways in prior empirical research (Barbuto and Wheeler, 2006; Ehrhart 2004; Laub 1999; Liden et al. 2008; Sendjaya et al. 2008), and there is no overall consensus regarding the exact behaviors that constitute servant leadership (Parris and Welty Peachey 2013), most empirical studies adopt Greenleaf's (1977) definition of a servant leader as one who focuses on developing and empowering his/her followers, while at the same time encouraging the followers to act as servant leaders themselves (Parris and Welty Peachey 2013). For the purposes of this study, we adopt Ehrhart's (2004) global measure of servant leadership, which highlights seven main behaviors exhibited by servant leaders: putting subordinates first, forming relationships with subordinates, helping subordinates to develop and succeed, having conceptual skills, empowering subordinates, behaving ethically, and creating value for those outside the organization. Ehrhart's conceptualization of servant leadership is similar to that of other widely adopted scales (e.g., Laub, 1999; Liden et al. 2008; Senjaya et al. 2008). For example, the seven behaviors highlighted by Ehrhart (2004) overlap with six out of the seven dimensions captured by Liden et al.'s (2008) multi-dimensional scale (i.e., putting subordinates first, helping subordinates grow and succeed, having conceptual skills, empowering subordinates, behaving ethically and creating value for the community). In addition, Ehrhart's measure shares some similarities with four of the six dimensions from Laub's (1999) multi-dimensional scale. It examines the extent to which the leader emphasizes subordinate development (e.g., values and develops people), empowers subordinates (e.g., shares leadership), and creates value for the community (e.g., builds community). Ehrhart's (2004) measure also corresponds to four of six dimensions in Sendjaya et al.'s (2008) scale; 
voluntary subordination, covenantal relationship, transforming influence, and responsible morality. Ehrhart's (2004) measure has also been validated at the individual level of analysis in prior empirical work in the Chinese organizational context (Miao et al. 2014). While there are other measures of servant leadership available (see Parris and Welty Peachey 2013 for a review), we excluded most of them because they exclude ethical moral dimension within the constructs the scales are purported to measure. Servant leadership is a moral-laden approach to leadership hence, as Ehrhart (2004) rightly contends, apart from prioritization of subordinates' concerns, ethical behavior is a distinguishing characteristic of this construct. We believe that it is essential to employ a scale that is conceptually parsimonious with the theorizing of the construct. Liden's (2008) and Sendjaya et al.'s (2008) scales include the ethical dimensions, but in the absence of a 'gold standard' of servant leadership measure, we believe it is prudent to use the most theoretically reliable and empirically validated global scale of servant leadership based on extant literature at the time of our study.

Although servant leadership shares some commonalities with other leadership styles, such as transformational and empowering leadership, given its focus on follower development and empowerment, there is growing evidence that it is conceptually distinct and has incremental predictive validity (Ehrhart 2004; Liden et al. 2008; Parolini et al. 2009; Peterson et al. 2012; Reed 2015; Schaubroeck et al. 2011; Schneider and George 2011). In addition, although it shares a moral component with ethical leadership (Brown et al. 2005), it is more inclusive given its stress on both acting ethically and providing service to the wider community.

Servant Leadership and Follower OCB

Although there is growing research linking servant leadership to follower job performance (Jaramillo et al. 2009; Liden et al. 2008), limited work has focused on its positive influence in eliciting follower OCB (Ehrhart 2004; Hunter et al. 2013; Walumbwa et al. 2010). While 
some studies have looked at the mechanisms linking servant leadership to workplace outcomes, these have typically been conducted at the team level, through the examination of mechanisms such as team-level procedural justice and service climate (Ehrhart 2004; Hunter et al. 2013; Walumbwa et al. 2010). In contrast, there has been limited examination of mediators at the individual level of analysis. Although recent research has begun to examine the effects of servant leadership on OCB at the individual level, it has not looked at the mechanisms that explain its effects (Ozyilmaz and Cicek 2015).

\section{Mediating Role of LMX}

LMX theory has been put forward as a mechanism that explains the process by which servant leaders influence their followers to go above and beyond their job role and engage in behavior that benefits the organization and other organizational members (Van Dierendonck 2011; Henderson et al. 2009). For example, Van Dierendonck (2011) proposes that servant leaders influence follower's extra-role behavior such as OCB through the development of high-quality social exchange relationships characterized by the reciprocated exchange of care and concern.

LMX refers to the degree of emotional support and exchange of valuable resources between a supervisor and his/her direct subordinate (Liden et al. 2008). In other words, it measures the extent to which both parties engage in a process of reciprocated social exchange (Masterson et al. 2000). Relationships high in LMX are characterized by high levels of mutual trust, respect and obligation (Nie and Lämsä 2013).

Although there has been a dearth of empirical work linking leadership behavior to LMX development, recent studies highlight a positive relationship between leadership behaviors such as transformational, moral or ethical leadership and follower perceptions of LMX (Gu 2015; Walumbwa et al. 2011; Wang et al. 2005). These studies also find that LMX 
mediates the influence of such leadership behaviors on follower work outcomes such as job performance, creativity and OCB.

We might expect servant leadership to elicit high levels of LMX for a number of reasons. First, by focusing on the development of their followers and providing opportunities to learn new skills (Smith et al. 2004), servant leaders facilitate the development of strong interpersonal relationships with their followers. Indeed, widely used measures of servant leadership highlight relationship building with subordinates and the provision of support to subordinates to enable them to develop and succeed, as key behaviors exhibited by servant leaders (Ehrhart 2004; Laub 1999; Liden et al. 2008). Second, by soliciting followers' ideas and encouraging them to become involved in decision-making (Hunter et al. 2013), servant leaders are able to build high-quality LMX relationships with their followers that go beyond specified economic exchange. Third, by stressing to their followers the importance of making a contribution to society and following through on promises (Walumbwa et al. 2010), servant leaders are seen as principled decision-makers who care about others. This will lead followers to perceive that such leaders are acting in their best interests, resulting in enhanced LMX from higher levels of loyalty and emotional connectedness. Although some researchers have suggested that leaders may develop differentiated LMX relationships with their followers, Henderson et al. (2009) argue that servant leaders are concerned with developing and engaging all of their followers. By establishing high-quality working relationships with all of their subordinates, servant leaders minimize LMX differentiation within the team.

In addition to enhancing LMX, servant leadership is also likely to enhance follower OCB through the development of high-quality LMX relationships. Strong LMX relationships are characterized by high levels of trust and support between leader and follower as well as the exchange of both material and non-material benefits, above the specifications of the job description (Ilies et al. 2007; Liden et al. 2008). To reciprocate the development of strong 
LMX relationships and maintain a balanced and equitable social exchange with their leader, followers are likely to go beyond what is required of them in their job description through the exhibition of OCB (Wayne et al. 2002). In support of such assertions, recent meta-analyses of empirical work highlight a strong relationship between LMX and OCB (Dulebohn et al. 2012; Ilies et al. 2007). Given such findings, we would expect LMX to mediate the relationship between servant leadership and OCB. Based on the above arguments, we develop the following hypotheses:

Hypothesis 1 Servant leadership will be positively related to follower perceptions of LMX.

Hypothesis 2 Follower perceptions of LMX will mediate the relationship between servant leadership and follower OCB.

Mediating Role of Psychological Empowerment

Psychological empowerment has been conceptualized as a form of intrinsic motivation to perform tasks manifested in four dimensions: meaning, competence, self-determination and impact (Spreitzer 1995). Meaning refers to when individuals perceive their jobs as having value or importance (Zhang and Bartol 2010). Competence is the individual's feeling of selfefficacy or confidence that they have the skills and knowledge to complete the task at hand (Bandura 1986; Conger and Kanungo 1988). Self-determination refers to whether the individual feels that they have the freedom or autonomy to make decisions about how they perform their work (Avolio et al. 2004). Finally, impact reflects the extent to which individuals feel that their work makes a difference in achieving the purposes of a given task and organizational outcomes more generally (Avolio et al. 2004; Spreitzer 1995). Spreitzer 
(1995) demonstrated that the four dimensions, although empirically distinct, formed a higherorder construct of psychological empowerment.

Although researchers have argued that psychological empowerment is one of the main mechanisms by which servant leaders influence their followers' work outcomes (Liden et al. 2008; Russell and Stone 2002), no empirical work has been conducted to verify whether this is indeed the case. This is in spite of the fact that several major scales of servant leadership highlight empowerment as one of the key behaviors exhibited by servant leaders (Ehrhart 2004; Laub 1999; Liden et al. 2008). For example, both Ehrhart (2004) and Liden et al. (2008) highlight subordinate empowerment as a key characteristic of servant leaders, whereas Laub (1999) argues that servant leaders empower followers by engaging in shared leadership.

Servant leadership might be expected to lead to greater feelings of empowerment in followers for several reasons. First, by considering the needs of followers and providing them with opportunities for development (Ehrhart 2004; Liden et al. 2008; Stone et al. 2004), servant leaders should lead followers in perceiving their jobs as having value. In addition, by treating their followers with respect rather than simply using them for their own gain, servant leaders lead followers to experience a heightened sense of meaning in their jobs. Second, by treating followers with benevolence and responding to their individual developmental needs (Van Dierendonck 2011), servant leaders should enhance followers' confidence that they have the skills and knowledge to fulfill their job roles. Indeed, recent work by Walumbwa et al. (2010) finds strong evidence of a link between servant leadership and self-efficacy. In addition, by providing opportunities for followers to learn new skills and access training, servant leaders are also likely to foster followers' feelings of competence in their job. Third, because servant leaders provide followers with opportunities to participate in decisionmaking (Greenleaf 1977; Van Dierendonck 2011), they are likely to enhance followers' perceptions of self-determination. Indeed Laub (1999) highlights the provision of shared 
leadership as one of the key characteristics of servant leadership. Finally, by encouraging followers to become involved in decision-making, servant leaders provide opportunities for them to understand the impact that they have in their job and the organization as a whole. In summary, by enhancing followers' perceptions of meaning, competence, self-determination and impact, servant leadership is likely to enhance the psychological empowerment of individuals.

In addition to enhancing psychological empowerment, servant leadership can also be expected to enhance follower OCB through psychological empowerment because empowered employees are likely to take an active orientation to work and do more than is required in their job description (Kim and Kim 2013; Spreitzer 2008). Meaningfulness is likely to lead to higher OCB because it promotes a sense of attachment to the organization, not just to one's strictly defined role (Seibert et al. 2011). Competence and impact are also likely to encourage OCB because they will lead employees to see themselves as being more capable of achieving positive outcomes in their work if they exert the requisite effort (Spreitzer 1995). Indeed, a recent meta-analysis highlights a positive and statistically significant relationship between psychological empowerment and OCB (Seibert et al. 2011). Given such findings, we would expect psychological empowerment to mediate the relationship between servant leadership and OCB. Based on the arguments above, we develop the following hypotheses:

Hypothesis 3 Servant leadership will be positively related to follower psychological empowerment.

Hypothesis 4 Follower psychological empowerment will mediate the relationship between servant leadership and follower OCB.

Moderating Role of Proactive Personality 
Proactive personality refers to a behavioral tendency to identify opportunities to enact change and manipulate the environment to act on such opportunities (Crant 2000). Compared to more passive individuals, individuals high in proactive personality do not wait for information and opportunities to come to them, but instead actively seek new ideas and take the initiative to improve things (Fuller et al. 2012; Ng and Feldman 2013). They are more inclined to change their circumstances by individual means rather than let themselves be shaped by their environments (Bakker et al. 2012). In the workplace, proactive personality manifests itself in employees searching for new ideas to improve work practices, investing in skill development and seeking to understand organizational politics (Seibert et al. 2001).

Research over the last two decades has shown proactive personality to be conceptually independent from the 'Big Five' personality factors and to be predictive of follower behaviors not accounted for by the 'Big Five' (Bakker et al. 2012). For example, Major, Turner, and Fletcher (2006) found that the 'Big Five' personality factors accounted for approximately only $26 \%$ of the variance in proactive personality. In addition, they established that, after controlling for the 'Big Five', proactive personality explained unique variance in motivation to learn.

Although previous research has established that individuals high in proactive personality perform better in the workplace by developing social networks and strong LMX relationships with their supervisor (Li et al. 2010; Thompson 2005; Yang et al. 2011; Zhang et al. 2012) and exhibit higher levels of psychological empowerment (Fuller and Marler 2009), no research has examined how proactive personality influences follower responses to leadership behavior. In addition, despite the fact that recent work has established that servant leadership may result in more proactive followership behavior (Reed 2015), the extant literature has not examined whether a follower's proactive personality influences how followers respond to servant leadership. 
Given that recent work has shown that proactive individuals do not operate in a social vacuum but instead respond to different facets of the organizational and team context in which they are situated (Joo and Lim 2009; Thompson 2005), we propose that followers high in proactive personality will be more likely to benefit from working under a servant leader than more passive individuals. Specifically, we argue that when followers high in proactive personality work under a servant leader who acts unselfishly for their benefit, they will typically develop higher-quality LMX relationships and higher levels of psychological empowerment for several main reasons. First, because prior research has shown that proactive individuals are more likely to establish positive social exchange relationships with their supervisors to perform their jobs better (Li et al. 2010), we might expect such individuals to take greater advantage of the opportunities provided by servant leaders to become involved in decision-making and develop skills. In addition, proactive individuals are more likely to seek and act upon the extensive feedback provided by servant leaders than more passive individuals (Lam et al. 2007). This should lead them to develop higher-quality LMX relationships and go beyond what is required of them in their job description, to reciprocate their supervisor's positive treatment through the exhibition of OCB. From the supervisor's perspective, given that proactive individuals are more committed to work goals and exert higher levels of effort than passive individuals (Fuller et al. 2012), servant leaders should be more willing to provide them with support and autonomy in their work. This should further contribute to the development of a high-quality LMX relationship and lead to followers reciprocating by engaging in OCB that goes beyond formal expectations. Similarly, recent empirical research suggests that individuals with proactive personalities are more likely to respond to positive leadership behaviors, in terms of discretionary extra-role behaviors, through the development of high-quality LMX relationships with their supervisors. For example, Li et al. (2010) found that proactive personality led to higher OCB by 
facilitating LMX. Building on this work, Zhang et al. (2012) found that when the proactive personality of followers was higher than that of their leader, the followers exhibited higherquality LMX and improved work outcomes.

Second, as prior research has established a positive link between proactive personality and the intrinsic motivation of individuals (Fuller and Marler 2009), we might expect proactive individuals to exhibit higher levels of psychological empowerment because it has been conceptualized as a form of intrinsic motivation to perform tasks (Spreitzer 1995). As argued previously, this should in turn lead them to go beyond their job role and engage in discretionary OCB. However, in addition to its direct effects, we might expect proactive personality to interact with servant leadership and influence OCB by eliciting higher levels of psychological empowerment, considering the focus placed by servant leaders on empowering followers through the provision of work autonomy and participative decision-making (Ehrhart 2004). From the supervisor's perspective, given that proactive individuals are more likely to seek out new ideas and take the initiative (Fuller and Marler 2009), servant leaders are more likely to provide such individuals with greater autonomy. This should further contribute to their empowerment and lead them to engage in discretionary behavior in an attempt to maintain a balanced and equitable social exchange relationship. This leads us to the following hypotheses:

Hypothesis 5 Proactive personality will positively moderate the mediating effects of servant leadership on OCB through LMX.

Hypothesis 6 Proactive personality will positively moderate the mediating effects of servant leadership on OCB through psychological empowerment.

\section{Method}

Sample and Procedure 
A total of 446 supervisor-subordinate dyads from 30 teams within a large Chinese multinational firm participated in our study. At the end of 2013, the company had more than 90,000 employees and sales of more than 80 billion yuan. The data were collected in one subsidiary in which approximately 9,000 people are employed. We collected survey data from two sources (supervisors and their immediate subordinates) to minimize common method bias (Podsakoff et al. 2012). Prior to their distribution, the questionnaires were translated into Chinese from English by bilingual members of the research team using the back-translation procedure (Brislin 1993).

Data were collected in two phases. At time one, questionnaires were distributed to 500 subordinates in 30 teams. At time two, two weeks later, questionnaires were distributed to supervisors. Prospective respondents were assured that their responses were confidential and were informed of the voluntary nature of participation. Both sets of questionnaires were distributed in printed format and coded to ensure that the responses of the subordinates and their supervisors could be matched.

In all, 446 matched subordinate-supervisor responses were received, representing a response rate of 94 per cent. Of the subordinates, $73 \%$ were male, their mean age was 36.66 years $(\mathrm{SD}=8.22)$, and on average, they had worked under their present supervisor for just over three years $(\mathrm{M}=3.23, \mathrm{SD}=2.64)$.

Measures

\section{Servant Leadership}

Servant leadership was measured at the individual level using Ehrhart's (2004) 14-item global scale. Subordinates rated the servant leadership of their supervisor on a 5-point Likert scale $(1=$ strongly disagree, $5=$ strongly agree $)$. Sample items included 'My supervisor creates a sense of community among department employees' and 'My supervisor makes the 
personal development of department employees a priority'. The Cronbach's alpha for this scale was .93. This measure of servant leadership was chosen over competing measures for a number of reasons. First, as highlighted in a review of the servant leadership literature (Parris and Welty Peachey 2013), it has been the most widely used and validated scale in prior research (Hunter et al. 2013; Jaramillo et al. 2009; Mayer et al. 2008; Miao et al. 2014; Neubert et al. 2008; Schneider and George 2011; Walumbwa et al. 2010), and shares significant theoretical and empirical overlap with other measures of servant leadership (as highlighted earlier in the paper). Although some researchers have used multidimensional measures (e.g., Liden et al. 2008 and Laub 1999), recent research argues that servant leadership is better captured using a global scale than a multidimensional scale because it is not a higher-level construct, due to the fact that its underlying dimensions capture different aspects of leader behavior (Liden et al. 2015). The second main reason for adopting Ehrhart's scale was that it has been used in previous research to measure servant leadership at the individual level and in the Chinese cultural context (Miao et al. 2014).

\section{Leader/Member Exchange (LMX)}

LMX was measured using the LMX-7 scale (Graen and Uhl-Bien 1995; Scandura and Graen 1984). Subordinates self-rated each item on a 5 -point Likert scale $(1=$ strongly disagree, $5=$ strongly agree). Sample items included 'I have a good working relationship with my supervisor' and 'My supervisor understands my problems and needs'. The Cronbach's alpha for this scale was .88 .

\section{Psychological Empowerment}

Spreitzer's (1995) 12-item scale was adopted to measure psychological empowerment. Subordinates self-rated each item on a 5 -point Likert scale $(1=$ strongly disagree, $5=$ strongly agree). The measure is composed of four subscales: meaning, competence, self- 
determination and impact. An example item from each subscale is 'The work I do is very important to me' (meaning); 'I am confident about my ability to do my job' (competence); 'I have significant autonomy in determining how I do my job' (self-determination); and 'My impact on what happens in my department is large' (impact). Following Spreitzer (1995), we averaged scores from the four subscales to form a single empowerment score for each respondent. The Cronbach's alpha for the total psychological empowerment scale was .94.

\section{Proactive Personality}

Proactive personality was self-rated by subordinates on a 5-point Likert scale $(1=$ strongly disagree, 5 = strongly agree) using the 10-item Proactive Personality Scale developed by Seibert et al. (1999). Sample items included 'Nothing is more exciting than seeing my ideas turn into reality' and 'Wherever I have been, I have been a powerful force for constructive change'. The Cronbach's alpha for this scale was .82.

\section{Organizational Citizenship Behavior (OCB)}

OCB-I and OCB-O were measured by a 16-item scale (eight items for each dimension) developed and validated by Lee and Allen (2002). Sample items for OCB-I included 'Helps others who have been absent' and 'Goes out of way to make new employees feel welcome in the work group'. Sample items for OCB-O included: 'Attend functions that are not required but that help the organizational image' and 'Offer ideas to improve the functioning of the organization'. Supervisors rated the OCB of their subordinates on a 5-point Likert scale $(1=$ strongly disagree, $5=$ strongly agree). Following recent recommendations in the literature (Hoffman et al. 2007; Walumbwa et al. 2010), we combined the two dimensions because we were interested in an overall measure of OCB for the purposes of hypothesis testing. The Cronbach's alpha for the total OCB scale was .93 . 


\section{Control Variables}

To control for potential confounding effects, we included age and supervisor tenure (both measured in years) and gender (coded $1=$ male, $0=$ female) as controls in line with previous research (Zhu et al. 2013). We did not control for organizational tenure because it was very highly correlated with age $(r=.92)$.

\section{Method of Analysis}

We tested our hypotheses using ordinary least squares (OLS) regression with the conditional process modeling (PROCESS) program for SPSS (Hayes 2013). To reduce problems associated with multicollinearity in moderated regression, all variables were z-standardized prior to analysis (Tabachnick and Fidell 2013). Evaluation of regression assumptions of normality, homoscedasticity, linearity, and absence of multicollinearity were satisfactory.

Given that we were examining the interactive effects between servant leadership and an individual-level personality variable, it is appropriate to conduct this analysis at the individual (within-team) level rather than between team-level. However, it is important to control for non-independence in ratings among subordinates reporting to the same supervisor. Given the relatively small number of supervisors in the present study we report fixed effects specifications. A fixed effects model is a commonly used extension of OLS regression whereby each unit (or supervisor in our case) has its own intercept. These fixed effects were captured in the present study by including K-1 dummy variables, identifying the 30 supervisors. The major advantage of a fixed effect model is that we control for any unobserved heterogeneity (reflecting non-independence and omitted variables) correlated with supervisor membership. To test the robustness of our fixed effects, we also estimated random-coefficients models (Cohen et al. 2003). Following Kenny et al.'s (2003) approach for lower-level mediation, we examined if the paths (slope coefficients) that defined the 
indirect effects for LMX and psychological empowerment were random (i.e., heterogeneous across supervisors). We did not find statistically significant variance in slope estimates across supervisors: servant leadership to LMX (slope variance $=.01, \mathrm{p}>.05$ ), servant leadership to psychological empowerment (slope variance $=.01, \mathrm{p}>.05$ ), LMX to OCB (slope variance $=.02, \mathrm{p}>.05$ ), and psychological empowerment to OCB (slope variance $=.01, \mathrm{p}>.05)$. From these results we can infer that the slopes can be treated as fixed (non-random).

\section{Results}

Table 1 reports the means, standard deviations and correlations of the study variables. Consistent with our theoretical expectations, the zero-order correlations for servant leadership, LMX, psychological empowerment and OCB were all in the expected direction, with the strongest correlation between LMX and psychological empowerment $(r=.58)$. As expected, LMX and empowerment were significantly related to the independent variable, servant leadership, and the dependent variable, OCB. This suggests that it is appropriate to proceed with more formal mediation analysis. Age, gender and supervisor tenure were positively correlated with OCB, supporting their inclusion as covariates in our regression models. Interestingly, the correlations for gender show that males were rated as having higher levels of OCB and greater self-reported LMX and psychological empowerment than females.

\section{INSERT TABLE 1 ABOUT HERE}

\section{Construct Validity}

We first conducted a confirmatory factor analysis using LISREL 8.80 to establish discriminant validity between the study variables. Scale items were used as indicators for all constructs except for psychological empowerment, where, consistent with previous research 
(Spreitzer, 1995), the four dimensions of empowerment were used as indicators. As shown in Table 2, the hypothesized five-factor model (i.e., servant leadership, LMX, psychological empowerment, proactive personality and OCB) yielded an acceptable fit to the data $\chi^{2}(d f=$ 1214) $=3601 ;$ RMSEA $=.07$, TLI $=.95$, CFI $=.95$, SRMR $=.07$. Standardized factor loadings on the five factors were acceptable, averaging .66. Correcting for measurement error, the average inter-correlation among the five factors was .40 . We also examined a model with the four self-reported constructs that were likely to be susceptible to common method variance (i.e., excluding OCB). This four-factor model had almost identical fit to the hypothesized five-factor model. As shown in Table 2, the hypothesized models were a better fit than all alternative models, providing evidence of discriminant validity. Taken together, these results provide evidence for construct validity of the measures used in this study.

\section{INSERT TABLE 2 ABOUT HERE}

As shown in Table 3, Model 1, there was a strong positive relationship between servant leadership and LMX $(\beta=.64, \mathrm{p}<.01)$. Hence, Hypothesis 1 was supported. A bias-corrected bootstrap using 1,000 resamples found that the indirect effect of servant leadership on OCB through LMX (with psychological empowerment controlled) was $.06(95 \% \mathrm{CI}=.01$ to .12$)$. As zero is not contained in the $95 \%$ confidence interval for the indirect effect, Hypothesis 2 was supported.

In support of Hypothesis 3, servant leadership was positively related to psychological empowerment $(\beta=.46, p<.01)$ (see Table 3, Model 2$)$. The indirect effect of servant leadership on OCB through psychological empowerment (with LMX controlled) was .01 (95\% $\mathrm{CI}=-.03$ to .06$)$. As zero is contained in the $95 \%$ confidence interval for the indirect effect, Hypothesis 4 was not supported. 
Finally, as shown in Table 3, Model 3, the direct effect of servant leadership on OCB was not statistically significant $(\beta=-.01, p>.05)$, supporting an inference of full mediation. Overall, our mediation model explained approximately $10 \%$ of the variance in OCB, an amount comparable to other studies using supervisor ratings of extra-role behavior (Podsakoff et al. 2000).

\section{INSERT TABLE 3 ABOUT HERE}

\section{Mediation}

To test Hypotheses 2 and 4, we conducted mediated regression analyses with bias-corrected bootstrapping of the indirect (mediated) effect. As recommended for testing multi-mediator models (Hayes 2013), we included both LMX and psychological empowerment simultaneously in our mediation model (also known as a parallel mediator model). A biascorrected bootstrap using 1,000 resamples found that the indirect effect of servant leadership on OCB through LMX (with psychological empowerment also included as a mediator in the model was $.06(95 \% \mathrm{CI}=.01$ to .13$)$. Because zero is not contained in the $95 \%$ confidence interval for the indirect effect, Hypothesis 2 was supported.

The indirect effect of servant leadership on OCB through psychological empowerment (with LMX also included as a mediator in the model) was .01 (95\% CI $=-.03$ to .06 ). Because zero is contained in the $95 \%$ confidence interval for the indirect effect, Hypothesis 4 was not supported. Finally, as shown in Table 3, Model 3, the direct effect of servant leadership on OCB was not statistically significant $(\beta=-.01, p>.05)$, supporting an inference of full mediation. Overall, our mediation model explained approximately $10 \%$ of the variance in $\mathrm{OCB}$, an amount comparable to other studies using supervisor ratings of extra-role behavior (Podsakoff et al. 2000). 
Moderated Mediation: The Moderating Effect of Proactive Personality

To test the moderated mediation relationship suggested in Hypotheses 5 and 6, we followed the approach outlined by Hayes (2013). Consistent with our theoretical arguments outlined previously, in our model proactive personality moderated the path from servant leadership to both LMX and psychological empowerment. Expressed in path-analytic language, the moderation effect was hypothesized to occur at the first stage (independent variable to mediator) of the mediation model (Edwards and Lambert 2007). As shown in Table 3, Models 4 and 5, the servant leadership proactive personality interaction was statistically significant for $\operatorname{LMX}(\beta=.11, p<.05)$ but not for psychological empowerment $(\beta=-.03$, $p>.05)$

To aid in interpreting the moderated effect for LMX, we plotted the statistically significant interaction (Cohen et al. 2003). As shown in Figure 2, the relationship between servant leadership and LMX was stronger when proactive personality was above average (one SD above the mean) than when below average (one SD below the mean). For robustness, we also tested if there was a moderation effect of proactive personality on the second stage (mediator to dependent variable) of our mediation model. Neither the LMX-OCB relationship $(\beta=.07, p>.05)$ nor the psychological empowerment-OCB relationship $(\beta=-.04, p>.05)$ were moderated by proactive personality.

\section{INSERT FIGURE 2 ABOUT HERE}

Taken together, these results support an inference of moderated mediation for LMX (Hypothesis 5) but not for psychological empowerment (Hypothesis 6). We proceeded to calculate the conditional (simple) indirect effect of servant leadership on OCB through LMX. The conditional indirect effect measures the strength of the indirect effect at different values 
(levels) of the moderator (in this case proactive personality). As recommended by Hayes (2013), we examined the statistical significance of the conditional indirect effect at one SD below and one SD above the mean for proactive personality. A bias-corrected bootstrap using 1,000 resamples found that the conditional indirect effect for LMX was weakest at one SD below the mean for proactive personality (bootstrapped indirect effect $=.05 ; 95 \% \mathrm{CI}: .01$ to .10). The conditional indirect effect for LMX was strongest at one SD above the mean value of proactive personality (bootstrapped indirect effect $=.07 ; 95 \% \mathrm{CI}$ : .01 to .14 ). Overall, these results support Hypothesis 5.

\section{INSERT TABLE 4 ABOUT HERE}

\section{Discussion}

In the present study, we found that LMX mediated the positive relationship between servant leadership and OCB. However, although servant leadership was positively related to psychological empowerment, the mediating influence of psychological empowerment did not explain any additional variance in OCB above that accounted for by LMX. We also found that subordinates' proactive personality moderated the indirect effect of servant leadership on subordinate OCB through LMX. These findings provide a number of theoretical implications for the leadership literature.

First, by examining the relative importance of LMX and psychological empowerment as mediators of the relationship between servant leadership and OCB, the present study establishes the salience of two competing mechanisms that have been identified in the literature as potential mediators by which servant leadership transmits its effects. In contrast to previous work on transformational leadership, which highlights the importance of 
psychological empowerment as a mechanism that transmits the effects of such leadership styles on follower work outcomes (Avolio et al. 2004), our research suggests that servant leadership primarily exerts its influence on followers at the individual level by facilitating social exchange between them and the leader, measured by high-quality LMX. Our findings suggest that because servant leaders put followers' development and interests above those of the organization, followers working under servant leaders develop intense personal bonds marked by shared values, open-ended commitment, mutual trust, and concern for the welfare of the other party. This in turn leads them to reciprocate in the form of discretionary behaviors that benefit the leader. This is supportive of social exchange theory and previous work by Sendjaya and Pekerti (2009), who highlighted the reciprocal nature of servant leadership behavior by which its recipients are likely to voluntarily return the favor, not out of specified obligation, but out of gratitude to the leader and the organization.

Although servant leadership was positively related to psychological empowerment as manifested in the four dimensions of meaning, competence, self-determination and impact (Spreitzer 1995), psychological empowerment did not lead followers to engage in discretionary behavior above and beyond that accounted for by LMX. These findings may result from the cultural context in which the research was conducted. More specifically because Chinese culture is characterized by high levels of collectivism and power-distance (Bond et al. 1985), employees are more likely to go above and beyond their job role and engage in OCB when they have a high-quality social exchange relationship with members of their work group, especially their supervisor (Lin 2010). For example, recent research revealed a positive relationship between the strength of the supervisor-subordinate social exchange relationship and subordinate OCB (Chou et al. 2014; Liu and Wang 2013). In addition, our findings may be explained by the fact that participants in our study were nonmanagerial employees, who typically exhibit a greater need for affiliation with other 
members of their work group and place less importance on autonomy at work. Recent work on participative leadership in China (Huang et al. 2010) found that psychological empowerment only mediated the relationship between participative leadership and OCB for managerial employees who had higher levels of autonomy in their job, in contrast to nonmanagerial employees, for whom it had no mediating influence. This suggests that nonmanagerial employees in China are only likely to engage in OCB when they have good relationships with other members of the work group, particularly their supervisor.

Our second contribution arises from examining the moderating impact of followers' proactive personality on the relationship between servant leadership and OCB through LMX. Our results suggest that followers with proactive personality respond more positively to servant leaders in terms of developing higher quality LMX relationships and OCB towards the organization and its members. By providing us with a deeper understanding of which types of followers respond more positively to servant leadership, the present research enables us to establish the boundary conditions under which servant leadership might be more effective. It also contributes to a growing literature examining how the individual differences of followers influence how they perceive and respond to their leaders (Antonakis et al. 2012).

Contrary to what was hypothesized, we found that the indirect effect of servant leadership on OCB through psychological empowerment was not stronger for those high in proactive personality (as opposed to low). These findings might be explained by the relatively high correlation between proactive personality and psychological empowerment and indicates that proactive individuals have higher levels of psychological empowerment irrespective of servant leadership (the latter was less strongly related to psychological empowerment than LMX). As a result, they are supportive of previous work that establishes a positive relationship between an individual's proactive personality and their intrinsic motivation (Fuller and Marler 2009). 
Our findings also have important managerial implications. We found that servant leadership is effective in fostering followers' OCB through eliciting high-quality LMX relationships rather than engendering a sense of meaning, competence, self-determination and impact. This suggests that followers value the quality of their relationship with the leader in terms of its profundity and genuineness over their sense of being empowered by the leader. We therefore recommend that leaders prioritize the cultivation of strong interpersonal relationships with followers and their development. This may sound deceptively obvious, but often leaders blissfully neglect this important-but-not-urgent agenda given their preoccupation with short-term goals. We recommend specifically that leaders demonstrate individualized concern and respect for followers, treat followers as equal partners in the organization, and mentor and facilitate others to be what they are capable of becoming. As the leader-follower reciprocal relationship grows, followers are more likely to engage in citizenship behaviors, which in the long run will benefit the organizational bottom line.

Given that followers with proactive personality were found to respond more positively to servant leadership in the form of higher LMX and greater OCB, we would also advise organizations to consider evaluating employees' proactive personality to advise manageriallevel staff of which employees would benefit more from the exercise of servant leadership. In addition, organizations might use information to match subordinates' proactive personalities with supervisors' leadership styles to maximize subordinate OCB, which benefits the organization.

\section{Limitations}

This study has some limitations that need to be considered when interpreting its findings. First, as the independent and mediating variables were collected at the same time, relationships among such variables should not be interpreted as causal. For example, followers with high levels of LMX or psychological empowerment might rate the servant 
leadership of their supervisors more favorably. Nevertheless, it is important to note that the results of our model are consistent with theoretical predictions based on extant research.

Second, because the data used in this study came from a single organization in China, its generalizability to other organizations and other industrial and cultural contexts may be brought into question. For example, the mediating effects of LMX on the relationship between servant leadership and OCB might be expected to be stronger in China due to a collectivistic and high power-distance culture where subordinates are more likely to reciprocate positive treatment from their supervisors in the form of discretionary behaviors such as OCB than in more individualistic and low power-distance cultures where there are fewer expectations that employees should reciprocate positive treatment (Westwood et al. 2004). This is supported by prior research which suggests that the effects of LMX on employee work outcomes might be stronger in China than in cultures that are more individualistic and lower in power distance (Wang et al. 2005).

\section{Suggestions for Future Research}

To determine the generalizability of our findings, similar research should be conducted in different industrial sectors and cultural contexts. In addition, to strengthen causal inferences, future research should adopt a longitudinal design to establish whether servant leadership enhances the development of LMX and psychological empowerment over time. Because our study did not control for the possible effects of other leadership approaches, such as transformational leadership (Choudhary et al. 2013), it would also be prudent for future studies to include other leadership approaches to further ascertain the additional variance explained by servant leadership on particular outcome variables. Finally, while other studies

(Ehrhart 2004; Hunter et al. 2013; Walumbwa et al. 2010) have analyzed team-level mediating mechanisms of servant leadership and $\mathrm{OCB}$, more work needs to be done to examine the link between servant leadership and OCB in groups, for example, on the 
influence of servant leadership on OCB group norms that usually influence individual-level behavior (Raver et al. 2012).

\section{Conclusion}

The present study contributes to the growing literature on servant leadership by examining the underlying mechanisms linking servant leadership and follower OCB, as well as examining whether follower's proactive personality accentuates the effects of servant leadership on OCB through such mechanisms. In line with social exchange theory, our findings demonstrate that servant leadership leads followers to engage in OCB by enhancing the quality of their relationship with their supervisor, as captured by LMX, rather than by enhancing their psychological empowerment. In addition, we found that followers high in proactive personality responded more positively to servant leadership than those low in proactive personality.

As well as helping us to understand why servant leadership leads followers to engage in greater discretionary behaviors that benefit the organization, the present study identifies which followers may respond more positively to servant leadership. This allows us to address the calls of researchers for additional studies about how individual differences among followers influence how they respond to different styles of leadership (Antonakis et al. 2012; Zaccaro 2012). We hope this provides a basis from which other scholars can conduct future research in this area. 


\section{References}

Antonakis, J., Day, D. V., \& Schyns, B. (2012). Leadership and individual differences: At the cusp of a renaissance. Leadership Quarterly, 23(4), 643-650.

Avolio, B. J., Zhu, W., Koh, W., \& Bhatia, P. (2004). Transformational leadership and organizational commitment: Mediating role of psychological empowerment and moderating role of structural distance. Journal of Organizational Behavior, 25(8), 951-968.

Avolio, B. J., Walumbwa, F. O., \& Weber, T. J. (2009). Leadership: Current theories, research, and future directions. Annual Review of Psychology, 60, 421-449.

Bakker, A. B., Tims, M., \& Derks, D. (2012). Proactive personality and job performance: The role of job crafting and work engagement. Human Relations, 65(10), 1359-1378.

Bandura, A. (1986). Social foundations of thought and action: A social cognitive theory. Englewood Cliffs, NJ: Prentice-Hall.

Blau, P. (1964). Exchange and power in social life. New York: Wiley.

Bond, M. H., Wan, K. C., Leung, K., \& Giacalone, R. A. (1985). How are responses to verbal insult related to cultural collectivism and power distance? Journal of Cross-Cultural Psychology, 16(1), 111-127.

Brislin, R. (1993). Understanding culture's influence on behavior. Fort Worth, TX: Harcourt Brace Publishers.

Brown, M. E., Trevino, L. K., \& Harrison, D. A. (2005). Ethical leadership: A social learning perspective for construct development and testing. Organizational Behavior and Human Decision Processes, 97(2), 117-134.

Carter, D., \& Baghurst, T. (2013). The influence of servant leadership on restaurant employee engagement. Journal of Business Ethics, 124(3), 453-464. 
Chou, S. Y., Han, B., \& Zhang, X. (2014). Effect of guanxi on Chinese subordinates' work behaviors: A conceptual framework. Asia-Pacific Journal of Business Administration, $6(1), 18-35$.

Choudhary, A. I., Akhtar, S. A., \& Zaheer, A. Impact of transformational and servant leadership on organizational performance: A comparative analysis. Journal of Business Ethics, 116(2), 433-440.

Cohen, J., Cohen, P., West, S. G., \& Aiken, L. S. (2003). Applied regression/correlation analysis for the behavioral sciences. Mahwah, NJ: Lawrence Erlbaum Associates.

Conger, J. A., \& Kanungo, R. N. (1988). The empowerment process: Integrating theory and practice. Academy of Management Review, 13(3), 471-482.

Crant, J. M. (2000). Proactive behavior in organizations. Journal of Management, 26(3), $435-462$.

Dulebohn, J. H., Bommer, W. H., Liden, R. C., Brouer, R. L., \& Ferris, G. R. (2012). A metaanalysis of antecedents and consequences of leader-member exchange: Integrating the past with an eye toward the future. Journal of Management, 38(6), 1715-1759.

Edwards, J. R., \& Lambert, L. S. (2007). Methods for integrating moderation and mediation: A general analytical framework using moderated path analysis. Psychological Methods, 12(1), 1-22.

Ehrhart, M. G. (2004). Leadership and procedural justice climate as antecedents of unit-level organizational citizenship behavior. Personnel Psychology, 57(1), 61-94.

Ehrhart, M. G., \& Klein, K. J. (2001). Predicting followers' preferences for charismatic leadership: The influence of follower values and personality. Leadership Quarterly, $12(2), 153-179$.

Fuller, J. B., \& Marler, L. E. (2009). Change-driven by nature: A meta-analytic review of the proactive personality literature. Journal of Vocational Behavior, 75(3), 329-345. 
Fuller, J. B., Marler, L. E., \& Hester, K. (2012). Bridge building within the province of proactivity. Journal of Organizational Behavior, 33(8), 1053-1070.

Graen, G. B., \& Uhl-Bien, M. (1995). Relationship-based approach to leadership: Development of leader/member exchange (LMX) theory of leadership over 25 years: Applying a multi-level multi-domain perspective. Leadership Quarterly, 6(2), 219247.

Greenleaf, R. K. (1977). Servant leadership: A journey into the nature of legitimate power and greatness. New York: Paulist Press.

Gu, Q., Tang, T. L.-P., \& Jiang, W. 2015. Does moral leadership enhance employee creativity? Employee identification with leader and leader-member exchange (LMX) in the Chinese context. Journal of Business Ethics, 126(3), 513-529.

Hayes, A. F. (2013). Introduction to mediation, moderation, and conditional process analysis. New York: The Guilford Press.

Henderson, D. J., Liden, R. C., Glibkowski, B. C., \& Chaudhry, A. (2009). LMX differentiation: A multilevel review and examination of its antecedents and outcomes. Leadership Quarterly, 20(4), 517-534.

Hoffman, B. J., Blair, C., Meriac, J., \& Woehr, D. J. (2007). Expanding the criterion domain? A meta-analysis of the OCB literature. Journal of Applied Psychology, 92(2), 555566.

Huang, X., Iun, J., Liu, A., \& Gong, Y. (2010). Does participative leadership enhance work performance by inducing empowerment or trust? The differential effects on managerial and non-managerial subordinates. Journal of Organizational Behavior, 31(1), 122-143. 
Hunter, E. M., Neubert, M. J., Perry, S. J., Witt, L. A., Penney, L. M., \& Weinberger, E. (2013). Servant leaders inspire servant followers: Antecedents and outcomes for employees and the organization. Leadership Quarterly, 24(2), 316-331.

Ilies, R., Nahrgang, J. D., \& Morgeson, F. P. (2007). Leader-member exchange and citizenship behaviors: A metaanalysis. Journal of Applied Psychology, 92(1), 269277.

Jaramillo, F., Grisaffe, D. B., Chonko, L. B., \& Roberts, J. A. (2009). Examining the impact of servant leadership on sales force performance. Journal of Personal Selling and Sales Management, 29(4), 257-275.

Joo, B. K., \& Lim, T. (2009). The effects of organizational learning culture, perceived job complexity, and proactive personality on organizational commitment and intrinsic motivation. Journal of Leadership \& Organizational Studies, 16(1), 48-60.

Kark, R., Shamir, B., \& Chen, G. (2003). The two faces of transformational leadership: Empowerment and dependence. Journal of Applied Psychology, 88(2), 246-255.

Kenny, D. A., Korchmaros, J. D., \& Bolger, N. (2003). Lower level mediation in multilevel models. Psychological Methods, 8(2), 115-128.

Kim, T.-Y., \& Kim, M. 2013. Leaders' moral competence and employee outcomes: The effects of psychological empowerment and person-supervisor fit. Journal of Business Ethics, 112(1), 155-166.

Lam, W., Huang, X., \& Snape, E. (2007). Feedback-seeking behavior and leader-member exchange: Do supervisor-attributed motives matter? Academy of Management Journal, $50(2), 348-363$.

Laub, J. (1999). Assessing the servant organization: Development of the Servant Organizational Leadership (SOLA) instrument. Dissertation Abstracts International, 60(2), 308 (UMI No. 9921922). 
Lee, K., \& Allen, N. J. (2002). Organizational citizenship behavior and workplace deviance: The role of affect and cognitions. Journal of Applied Psychology, 87(1), 131-142.

Li, N., Liang, J., \& Crant, J. M. (2010). The role of proactive personality in job satisfaction and organizational citizenship behavior: A relational perspective Journal of Applied Psychology, 95(2), 395-404.

Liden, R. C., Wayne, S. J., Liao, C., \& Meuser, J. D. (2014). Servant leadership and serving culture: Influence on individual and unit performance. Academy of Management Journal, 57(5), 1434-1452.

Liden, R. C., Wayne, S. J., \& Sparrowe, R. T. (2000). An examination of the mediating role of psychological empowerment on the relations between the job, interpersonal relationships, and work outcomes. Journal of Applied Psychology, 85(3), 407-416.

Liden, R. C., Wayne, S. J., Zhao, H., \& Henderson, D. (2008). Servant leadership: Development of a multidimensional measure and multilevel assessment. Leadership Quarterly, 19(2), 161-177.

Lin, L.-H., \& Ho, Y.-L. 2010. Guanxi and OCB: The Chinese cases. Journal of Business Ethics, 96(2), 285-298.

Liu, X. Y., \& Wang, J. (2013). Abusive supervision and organizational citizenship behaviour: is supervisor-subordinate guanxi a mediator? International Journal of Human Resource Management, 24(7), 1471-1489.

Major, D. A., Turner, J. E., \& Fletcher, T. D. (2006). Linking proactive personality and the Big Five to motivation to learn and development activity. Journal of Applied Psychology, 91(4), 927-935.

Masterson, S. S., Lewis, K., Goldman, B. M., \& Taylor, M. S. (2000). Integrating justice and social exchange: The differing effects of fair procedures and treatment on work relationships. Academy of Management Journal, 43(4), 738-748. 
Mayer, D. M., Bardes, M., \& Piccolo, R. F. (2008). Do servant-leaders help satisfy follower needs? An organizational justice perspective. European Journal of Work and Organizational Psychology, 17(2), 180-197.

Miao, Q., Newman, A., Schwarz, G., \& Xu, L. (2014). Servant leadership, trust, and the organizational commitment of public sector employees in China. Public Administration, 92(3), 727-743.

Neubert, M. J., Kacmar, K. M., Carlson, D. S., Chonko, L. B., \& Roberts, J. A. (2008). Regulatory focus as a mediator of the influence of initiating structure and servant leadership on employee behavior. Journal of Applied Psychology, 93(6), 1220-1233.

Ng, T. W. H., \& Feldman, D. C. (2013). Age and innovation-related behavior: The joint moderating effects of supervisor undermining and proactive personality. Journal of Organizational Behavior, 34(5), 583-606.

Nie, D., \& Lämsä, A.-M. (2015). The leader-member exchange theory in the Chinese context and the ethical challenges of Guanxi. Journal of Business Ethics, 128(4), 851-861.

Organ, D. W. (1988). Organizational citizenship behavior: The good soldier syndrome. Lexington, MA: Lexington Books.Ozyilmaz, A., \& Cicek, S. S. (2015). How does servant leadership affect employee attitudes, behaviors, and psychological climates in a for-profit organizational context? Journal of Management and Organization, 21(3), 263-290.

Parolini, J., Patterson, K., \& Winston, B. (2009). Distinguishing between transformational and servant leadership. Leadership \& Organization Development Journal, 30(3), 274 291.

Parris, D. L., \& Welty Peachey, J. (2013). A systematic literature review of servant leadership theory in organizational contexts. Journal of Business Ethics, 113(3), 377393. 
Peterson, S. J., Galvin, B. M., \& Lange, D. (2012). CEO servant leadership: Exploring executive characteristics and firm performance. Personnel Psychology, 65(3), 565596.

Podsakoff, P. M., MacKenzie, S. B., Paine, J. B., \& Bachrach, D. G. (2000). Organizational citizenship behaviors: A critical review of the theoretical and empirical literature and suggestions for future research. Journal of Management, 26(3), 513-563.

Podsakoff, P. M., MacKenzie, S. B., \& Podsakoff, N. P. (2012). Sources of method bias in social science research and recommendations on how to control it. Annual Review of Psychology, 63, 539-69.

Raver, J. L., Ehrhart, M. G., \& Chadwick, I. C. (2012). The emergence of team helping norms: Foundations within members' attributes and behavior. Journal of Organizational Behavior, 33(5), 616-637.

Reed, L. L. (2005). The big five personality traits as tools for retention of Florida 9-1-1 telecommunicators (Doctoral dissertation). Dissertations Abstracts International.

Reed, L. L. (2015). Servant leadership, followership, and organizational citizenship behaviors in 9-1-1 emergency communications centers: Implications of a national study. Servant Leadership Theory and Practice, 2(1), 71-94.

Reed, L. L., Vidaver-Cohen, D., \& Colwell, S. R. (2011). A new scale to measure executive servant leadership: Development, analysis, and implications for research. Journal of Business Ethics, 101(3), 415-434.

Russell, R. F., \& Stone, A. G. (2002). A review of servant leadership attributes: Developing a practical model. Leadership and Organization Development Journal, 23(3), 145-157.

Ryan, R. M., \& Deci, E. L. (2000). Self-determination theory and the facilitation of intrinsic motivation, social development, and well-being. American Psychologist, 55(1), 68-78. 
Scandura, T. A., \& Graen, G. B. (1984). Moderating effects of initial leader-member exchange status on the effects of a leadership intervention. Journal of Applied Psychology, 69(3), 428-436.

Schaubroeck, J., Lam, S. S. K., \& Peng, A. C. (2011). Cognition-based and affect-based trust as mediators of leader behavior influences on team performance. Journal of Applied Psychology, 96(4), 863-871.

Schneider, S. K., \& George, W. M. (2011). Servant leadership versus transformational leadership in voluntary service organizations. Leadership and Organization Development Journal, 32(1), 60-77.

Seibert, S. E., Crant, J. M., \& Kraimer, M. L. (1999). Proactive personality and career success. Journal of Applied Psychology, 84(3), 416-427.

Seibert, S. E., Kraimer, M. L., \& Crant, J. M. (2001). What do proactive people do? A longitudinal model linking proactive personality and career success. Personnel Psychology, 54(4), 845-974.

Seibert, S. E., Wang, G., \& Courtwright, S. H. (2011). Antecedents and consequences of psychological and team empowerment in organizations: A meta-analytic review. Journal of Applied Psychology, 96(5), 981-1003.

Sendjaya, S., \& Pekerti, A. (2010) Servant leadership as antecedent of trust in organizations. Leadership and Organization Development Journal, 31(7), 643-663.

Sendjaya, S., \& Sarros, J. C. (2002). Servant leadership: Its origin, development, and application in organizations. Journal of Leadership and Organizational Studies, 9(2), $57-64$.

Sendjaya, S., Sarros, J. C., \& Santora, J. C. (2008). Defining and measuring servant leadership behaviour in organizations. Journal of Management Studies, 45(2), 402424. 
Smith, B. N., Montagno, R. V., \& Kuzmenko, T. N. (2004). Transformational and servant leadership: Content and contextual comparisons. Journal of Leadership and Organizational Studies, 10(4), 80-92.

Spreitzer, G. M. (1995). Psychological empowerment in the workplace: Dimensions, measurement, and validation. Academy of Management Journal, 38(5), 1442-1465.

Spreitzer, G. M. (2008). Taking stock: A review of more than twenty years of research on empowerment at work. In J. Barling \& C. L. Cooper (Eds.), Handbook of organizational behavior (pp. 54-72). Thousand Oaks, CA: Sage.

Stone, A. G., Russell, R. F., \& Patterson, K. (2004). Transformational versus servant leadership: A difference in leader focus. Leadership and Organization Development Journal, 25(4), 349-361.

Tabachnick, B. G., \& Fidell, L. S. (2013). Using multivariate statistics (6 ${ }^{\text {th }}$ ed.). Boston: Pearson.

Thompson, J. A. (2005). Proactive personality and job performance: A social capital perspective. Journal of Applied Psychology, 90(5), 1011-1017.

Van Dierendonck, D. (2011). Servant leadership: A review and synthesis. Journal of Management, 37(4), 1228-1261.

Walumbwa, F. O., Hartnell, C. A., \& Oke, A. (2010). Servant leadership, procedural justice climate, service climate, employee attitudes, and organizational citizenship behavior: A cross-level investigation. Journal of Applied Psychology, 95(3), 517-529.

Walumbwa, F. O., Mayer, D. M., Wang, P., Wang, H., Workman, K., \& Christensen, A. L. (2011). Linking ethical leadership to employee performance: The roles of leadermember exchange, self-efficacy, and organizational identification. Organizational Behavior and Human Decision Processes, 115(2), 204-213. 
Walumbwa, F. O., Wang, P., Wang, H., Schaubroeck, J., \& Avolio, B. J. (2010). Psychological processes linking authentic leadership to follower behaviors. Leadership Quarterly, 21(5), 901-914.

Wang, H., Law, K. S., Hackett, R. D., Wang, D., \& Chen, Z. X. (2005). Leader-member exchange as a mediator of the relationship between transformational leadership and followers' performance and organizational citizenship behavior. Academy of Management Journal, 48(3), 420-432.

Wayne, S. J., Shore, L. M., Bommer, W. H., \& Tetrick, L. E. (2002). The role of fair treatment and rewards in perceptions of organizational support and leader-member exchange. Journal of Applied Psychology, 87(3), 590-598.

Westwood, R., Chan, A., \& Linstead, S. (2004). Theorizing Chinese employment relations comparatively: Exchange, reciprocity and the moral economy. Asia-Pacific Journal of Management, 21(3), 365-389.

Yang, J., Gong, Y., \& Huo, Y. (2011). Proactive personality, social capital, helping, and turnover intentions. Journal of Managerial Psychology, 26(8), 739-760.

Zaccaro, S. J. (2012). Individual differences and leadership: Contributions to a new tipping point. Leadership Quarterly, 23(4), 718-728.

Zhang, X. M., \& Bartol, K. M. (2010). Linking empowering leadership and employee creativity: The influence of psychological empowerment, intrinsic motivation, and creative process engagement. Academy of Management Journal, 53(1), 107-128.

Zhang, Z., Wang, M., \& Shi, J. (2012). Leader-follower congruence in proactive personality and work outcomes: The mediating role of leader-member exchange. Academy of Management Journal, 55(1), 111-130. 
Zhu, W., Newman, A., Miao, Q., \& Hooke, A. (2013). Revisiting the mediating role of trust in transformational leadership effects: Do different types of trust make a difference? Leadership Quarterly, 24(1), 94-105. 
Table 1 Means, standard deviations, and correlations among the study variables.

\begin{tabular}{|c|c|c|c|c|c|c|c|c|c|c|}
\hline \multicolumn{2}{|c|}{ Variable } & \multirow{2}{*}{\begin{tabular}{|c|}
$\boldsymbol{M}$ \\
3.83
\end{tabular}} & \multirow{2}{*}{$\begin{array}{l}\boldsymbol{S D} \\
0.54\end{array}$} & \multirow{2}{*}{1} & \multirow[t]{2}{*}{2} & \multirow[t]{2}{*}{3} & \multirow[t]{2}{*}{4} & \multirow[t]{2}{*}{5} & \multirow[t]{2}{*}{6} & \multirow[t]{2}{*}{7} \\
\hline 1 & OCB & & & & & & & & & \\
\hline 2 & Servant leadership & 4.15 & 0.63 & $.15^{* *}$ & - & & & & & \\
\hline 3 & LMX & 3.81 & 0.69 & $.19^{* *}$ & $.63 * *$ & - & & & & \\
\hline 4 & Empowerment & 3.82 & 0.49 & $.15^{* *}$ & $.45 * *$ & $.58 * *$ & - & & & \\
\hline 5 & Proactive personality & 3.66 & 0.50 & -.04 & $.27 * *$ & $.38 * *$ & $.41 * *$ & - & & \\
\hline 6 & Gender & 0.73 & 0.44 & $.10^{*}$ & .07 & $.17 * *$ & $.21 * *$ & $.12 *$ & - & \\
\hline 7 & Age & 36.66 & 8.22 & $.15^{* *}$ & .03 & -.05 & $.10 *$ & $-.19 * *$ & -.03 & - \\
\hline 8 & Supervisor tenure & 3.23 & 2.64 & $.16^{* *}$ & .06 & -.02 & .09 & -.04 & -.02 & $.14^{* *}$ \\
\hline
\end{tabular}

$* p<.05,{ }^{*} p<.01$. Gender is coded as $1=$ male and $0=$ female. 
Table 2 Results of confirmatory factor analysis.

\begin{tabular}{|c|c|c|c|c|c|c|}
\hline Model & $\overline{X^{2}}$ & $d f$ & TLI & CFI & RMSEA & SRMR \\
\hline Hypothesized five-factor model & 3601 & 1214 & .95 & .95 & .07 & .07 \\
\hline $\begin{array}{l}\text { Hypothesized model (four self-reported } \\
\text { constructs only) }\end{array}$ & 1735 & 554 & .96 & .96 & .07 & .07 \\
\hline $\begin{array}{l}\text { Four-factor model: Servant leadership and } \\
\text { LMX combined }\end{array}$ & 5388 & 1218 & .93 & .93 & .09 & .07 \\
\hline $\begin{array}{l}\text { Four-factor model: Servant leadership and } \\
\text { psychological empowerment combined }\end{array}$ & 3920 & 1218 & .94 & .94 & .08 & .07 \\
\hline $\begin{array}{l}\text { Three-factor model: Servant leadership, } \\
\text { LMX and psychological empowerment } \\
\text { combined }\end{array}$ & 5732 & 1221 & .92 & .92 & .10 & .08 \\
\hline One-factor model (five-factors) & 15740 & 1224 & .83 & .84 & .17 & .15 \\
\hline $\begin{array}{l}\text { One-factor model (four self-reported } \\
\text { constructs only) }\end{array}$ & 5685 & 560 & .89 & .90 & .15 & .11 \\
\hline
\end{tabular}

$\mathbf{X}^{2}=$ normal-theory weighted least-squares chi-square. TLI is the Tucker-Lewis fit index; CFI, the comparative fit index; RMSEA, the root-mean-square error of approximation; and SRMR, the standardized root mean square residual. 